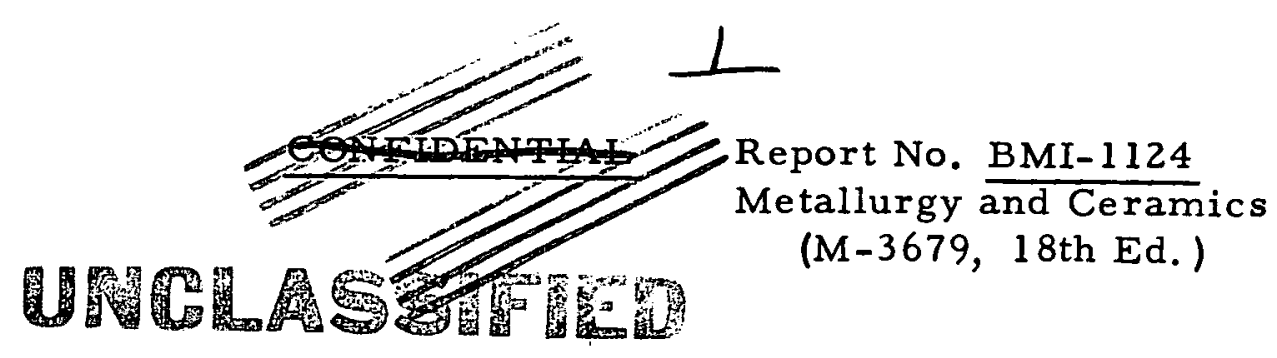

Contract No. W-7405-eng -92

\title{
SURVEY OF REFRACTORY URANIUM COMPOUNDS
}

by

Luther D. Loch

Glen B. Engle

M. Jack Snyder

Winston H. Duckworth

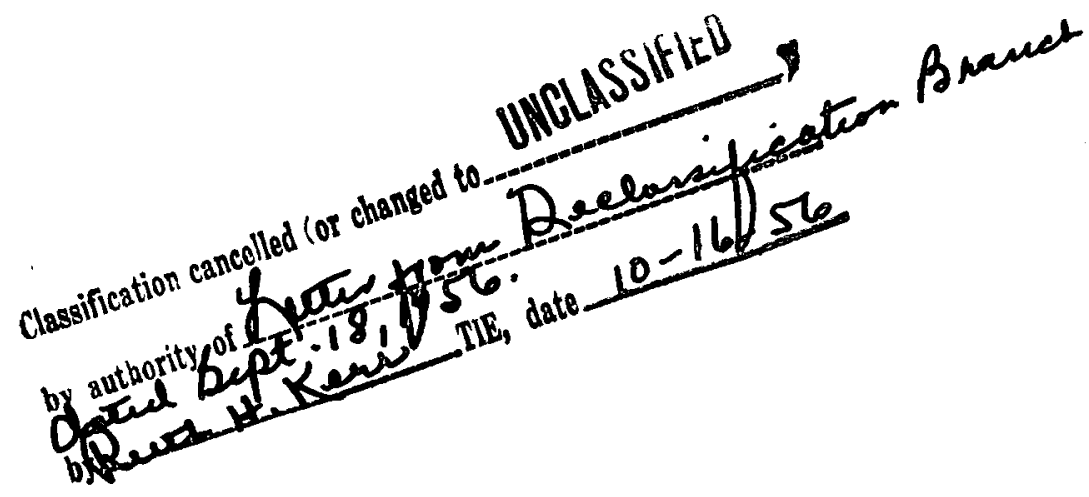

August $7,-1956$

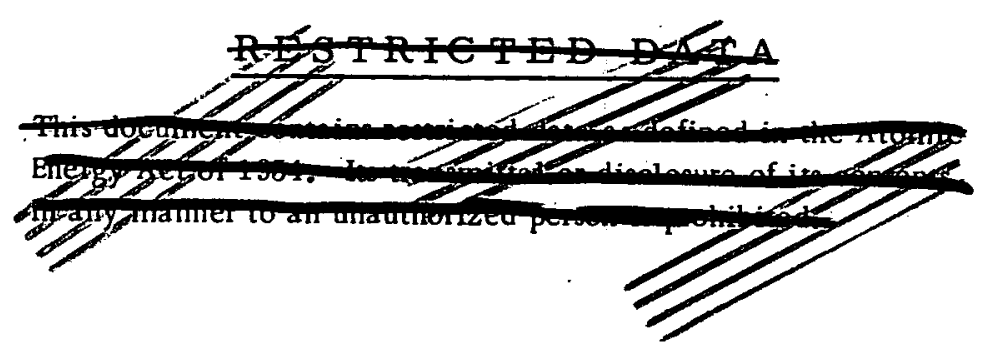

BATTELLE MEMORIAL INSTITUTE 505 King Avenue

Columbus 1, Ohio

UNCLASSGIFU

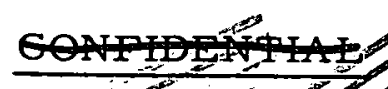




\section{DISCLAIMER}

This report was prepared as an account of work sponsored by an agency of the United States Government. Neither the United States Government nor any agency Thereof, nor any of their employees, makes any warranty, express or implied, or assumes any legal liability or responsibility for the accuracy, completeness, or usefulness of any information, apparatus, product, or process disclosed, or represents that its use would not infringe privately owned rights. Reference herein to any specific commercial product, process, or service by trade name, trademark, manufacturer, or otherwise does not necessarily constitute or imply its endorsement, recommendation, or favoring by the United States Government or any agency thereof. The views and opinions of authors expressed herein do not necessarily state or reflect those of the United States Government or any agency thereof. 


\section{DISCLAIMER}

Portions of this document may be illegible in electronic image products. Images are produced from the best available original document. 
$\underline{\text { Page }}$

ABSTRACT

INTRODUCTION

URANIUM CARBIDES, NITRIDES, AND SULFIDES • • • • • 6

Preparation . . . . . . . . . . . . . . . . 6

Crystallography . . . . . . . . . . . . . . 10

Thermochemical Aspects . . . . . . . . . . . . 10

Chemical Properties and Corrosion Data . . . . . . 15

Physical Properties . . . . . . . . . . . . . 18

URANIUM SILICIDES AND BORIDES

Preparation . . . . . . . . . . . . . . . . . . . 18

Crystallography . . . . . . . . . . . . . . . . . 18

Thermochemical Aspects . . . . . . . . . . . . 20

Chemical Properties and Corrosion Data . . . . . . 20

Physical Properties . . . . . . . . . . . . . 24

COMPOUNDS WITH METALS $\quad$ •

Preparation . . . . . . . . . . . . . . . . . . . . . 24

Crystallography . . . . . . . . . . . . . . . 24

Properties . . . . . . . . . . . . . . . . . . . . . . 28

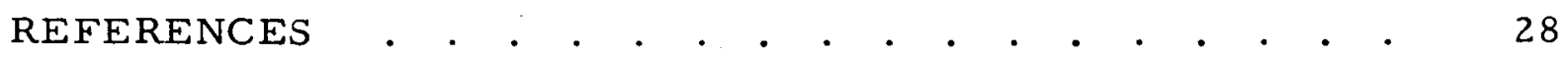




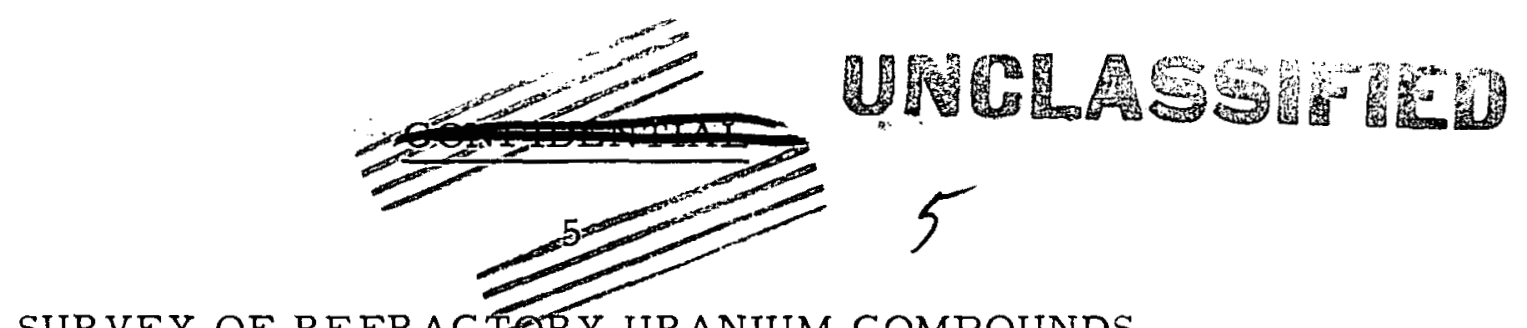

\title{
SURVEY OF REFRAC TORY URANIUM COMPOUNDS
}

Luther D. Loch, Glen B. Engle,

M. Jack Snyder, and Winston H. Duckworth

\begin{abstract}
Chemical and physical data on twenty binary uranium compounds that may prove suitable for refractory nuclear fuels were assembled. The compounds were those with aluminum, boron, carbon, iron, nickel, nitrogen, siliçon, or sulfur.

Too little is known at this time about the compounds to evaluate any of them for fuel. The program is being extended in an effort to provide the needed data.
\end{abstract}

\section{INTRODUCTION}

A need exists in our nuclear-energy program for fuel compounds that are stable at high temperatures. Considerable research and development is being done on one such compound, $\mathrm{UO}_{2}$. However, a number of other refractory uranium compounds are receiving little attention. The first phase of a research effort to supply needed data on them is summarized in this report.

As indicated, the present interest is in compounds that are resistant to melting or decomposition at high temperatures. Also, in general, a nuclear fuel should contain a high concentration of fissionable material and should have a low absorption cross section for slow neutrons. Other properties of particular interest in this program include vapor pressure, free energy of formation, thermal conductivity, thermal expansion, Young's modulus, and corrosion resistance.

The results of a literature survey are given in this report together with data obtained to date in a concurrent laboratory effort. Further reports will be issued as particular compounds are prepared and measurements of their properties are completed. 


\section{SELECTION OF COMPOUNDS}

Twenty binary uranium compounds, with aluminum, boron, carbon, iron, nickel, nitrogen, silicon, or sulfur, appeared interesting on the basis of uranium content and refractoriness. Compounds melting much below $800 \mathrm{C}$ were arbitrarily excluded. Melting points and uranium contents of the twenty compounds are shown in Table 1 . Two nitrides, $\mathrm{U}_{2} \mathrm{~N}_{3}$ and $\mathrm{UN}_{2}$, and one sulfide, $U S_{2}$, were excluded from Table 1 because of reported low stabilities at high temperatures $(1,2)$, although they had the desired high melting points and uranium contents.

Table 2 lists the absorption cross sections and comparative induced radioactivities for each of the eight combining elements in Table 1 . The induced activities were computed for $1 \mathrm{~g}$ of combining element irradiated for $1 \mathrm{yr}$ in a thermal-neutron flux of $10^{14}$ neutrons $/\left(\mathrm{cm}^{2}\right)(\mathrm{sec})$. In each case, in computing the activity, the decay chains were continued until a stable isotope was reached. In the case of boron, calculations were made for the low-absorption natural isotope, boron-1l.

For comparison with Table 2, the activity of the fission products of uranium-235 was estimated to be $1.85 \times 10^{11}$ curies per $\mathrm{g}, 1 \mathrm{hr}$ after removal from a reactor operating at a thermal flux of $10^{14} \mathrm{nv}$. Therefore, in each compound considered, the uranium will introduce a much larger amount of activity than is as sociated with the combining element.

\section{URANIUM CARBIDES, NITRIDES, AND SULFIDES}

\section{Preparation}

Uranium carbides, nitrides, or sulfides are prepared by a variety of reactions. Equations for these are given in Table 3.

The carbides usually are prepared by arc melting stoichiometric mixtures of the elements or by reaction of uranium oxides with carbon. The reaction of monatomic carbon and $\mathrm{UO}_{2}$ is carried out in a graphite crucible at about $1800 \mathrm{C}$. The reaction is essentially complete when the evolution of CO markedly decreases and should be stopped at this point to avoid further pickup of carbon from the crucible. $(6,8)$ UC can be prepared by passing methane over fine uranium powder (prepared from $\mathrm{UH}_{3}$ ) at 650-700 C. (7)

(1) References at end. 
TABLE 1. URANIUM CONTENTS AND MELTING POINTS OF URANIUM COMPOUNDS

\begin{tabular}{|c|c|c|c|c|}
\hline \multirow[b]{2}{*}{ Compound } & \multicolumn{2}{|c|}{ Uranium Content } & \multirow[b]{2}{*}{ Melting Point, $\mathrm{C}$} & \multirow[b]{2}{*}{ Reference } \\
\hline & $w / 0$ & $\mathrm{G}$ per $\mathrm{Cm}^{3}(\mathrm{a})$ & & \\
\hline $\mathrm{UC}$ & 95.19 & 12.97 & $2350-2400$ & (3) \\
\hline $\mathrm{U}_{2} \mathrm{C}_{3}$ & 92.97 & 11.97 & 1775 (decomposition) & (3) \\
\hline $\mathrm{UC}_{2}$ & 90.83 & 10.61 & $2450-2500$ & (3) \\
\hline UN & 94.44 & 13.52 & $2650 \pm 100$ & (4) \\
\hline US & 88.12 & 9.58 & $>2000$ & (1) \\
\hline $\mathrm{U}_{2} \mathrm{~S}_{3}$ & 83.40 & 7.32 & -- & \\
\hline $\mathrm{U}_{3} \mathrm{Si}$ & 96.21 & 14.99 & $930(\mathrm{~b})$ & (5) \\
\hline $\mathrm{U}_{3} \mathrm{Si}_{2}$ & 92.70 & 11.31 & $\sim 1650$ & (5) \\
\hline $\mathrm{USi}$ & 89.44 & 9.30 & $\sim 1600$ & (5) \\
\hline Alpha USi 2 & 80.91 & 7.27 & $\sim_{1600}$ & (5) \\
\hline Beta $\mathrm{USi}_{2}$ & 80.91 & 7.48 & $\sim_{1600}$ & (5) \\
\hline $\mathrm{USi}_{3}$ & 73.86 & 6.02 & $\sim 1500$ & (5) \\
\hline $\mathrm{UB}_{2}$ & 91.66 & 11.75 & $>1500$ & (6) \\
\hline $\mathrm{UB}_{4}$ & 84.61 & 7.94 & $>1500$ & (6) \\
\hline $\mathrm{U}_{6} \mathrm{Ni}$ & 96.05 & 16. 90 & $790(c)$ & (5) \\
\hline $\mathrm{UNi}_{2}$ & 66.98 & 9.02 & $985(c)$ & (5) \\
\hline $\mathrm{UNi}_{5}$ & 44.77 & -- & 1300 & (5) \\
\hline $\mathrm{UAl}_{2}$ & 81.52 & 6.64 & $\sim 1590$ & (5) \\
\hline $\mathrm{U}_{6} \mathrm{Fe}$ & 96.20 & 17.00 & $815^{(c)}$ & (5) \\
\hline $\mathrm{UFe}_{2}$ & 68.00 & 8.98 & 1235 & (5) \\
\hline
\end{tabular}

(a) Based on product of $\mathrm{X}$-ray density of compound and w/o uranium.

(b) Perite ctoid temperature.

(c) Peritectic temperature. 
TABLE 2. ABSORPTION CROSS SECTIONS AND INDUCED RADIOACTIVITIES OF COMBINING ELEMENTS IN REFRACTORY URANIUM COMPOUNDS

\begin{tabular}{lcc}
\hline \hline Element & $\begin{array}{c}\text { Thermal-Neutron-Absorption } \\
\text { Cross Section, } \\
\text { millibarns per atom }\end{array}$ & $\begin{array}{c}\text { Induced Activity (a), } \\
\text { curies per g of } \\
\text { element }\end{array}$ \\
\hline Carbon & 3.2 & 0.0000282 \\
Nitrogen & 1880 & 0.025 \\
Sulfur & 490 & 2.25 \\
Silicon & 130 & 0.2 \\
Boron- 11 & 50 & $0.738(\mathrm{~b})$ \\
Nickel & 4600 & 1.16 \\
Aluminum & 230 & 14.0 \\
Iron & 2530 & 3.77 \\
\hline \hline
\end{tabular}

(a) Activated for 1 yr in a thermal-neutron flux of $10^{14}$ neutrons $/\left(\mathrm{cm}^{2}\right)(\mathrm{sec})$.

(b) Three seconds after removal from the neutron flux this activity will be attenuated by a factor of $10^{-8}$. 
TABLE 3. PREPARATIONS OF URANIUM CARBIDES, NITRIDES, AND SULFIDES

\begin{tabular}{|c|c|c|c|c|}
\hline Compound & $\begin{array}{c}\text { Physical } \\
\text { Appearance }\end{array}$ & $\begin{array}{l}\text { Liquid-Solid } \\
\text { Reactions }\end{array}$ & $\begin{array}{l}\text { Solid-Solid } \\
\text { Reactions }\end{array}$ & $\begin{array}{l}\text { Gas-Solid } \\
\text { Reactions }\end{array}$ \\
\hline & & & Carbides & \\
\hline UC & $\begin{array}{l}\text { Bright hard } \\
\text { crystals }\end{array}$ & $\begin{array}{l}U+C \rightarrow U C(2100 C)^{(7)^{(a)}} \\
U+C \rightarrow U C(1600-1700 C)^{(8)}\end{array}$ & $\mathrm{UO}_{2}+3 \mathrm{C}-\mathrm{UC}+2 \mathrm{CO}(1750-1800 \mathrm{C})^{(6)}$ & $\begin{array}{l}\mathrm{U}+\mathrm{C}_{2} \mathrm{H}_{2} \rightarrow \mathrm{UC}+\mathrm{C}+\mathrm{H}_{2}^{(7)} \\
\mathrm{U}+\mathrm{CH}_{4} \rightarrow \mathrm{UC}+2 \mathrm{H}_{2}^{(7)}\end{array}$ \\
\hline $\mathrm{U}_{2} \mathrm{C}_{3}$ & $\begin{array}{l}\text { Bright hard } \\
\text { crystals }\end{array}$ & $2 U+3 C \rightarrow U C+U C_{2}(2000 C)^{(9)}$ & $U C+U C_{2} \rightarrow U_{2} C_{3}(1600 C)^{(9)}$ & \\
\hline$U C_{2}$ & $\begin{array}{l}\text { Gray metallic } \\
\text { crystals }\end{array}$ & $U+2 C \rightarrow U C_{2}^{(10)}$ & $\begin{array}{l}\mathrm{UO}_{2}+4 \mathrm{C} \rightarrow \mathrm{UC}_{2}+2 \mathrm{CO}(1750-1800 \mathrm{C})^{(8)} \\
\mathrm{U}_{3} \mathrm{O}_{8}+14 \mathrm{C} \rightarrow 3 \mathrm{UC}_{2}+8 \mathrm{CO}(2400 \mathrm{C})^{(10)}\end{array}$ & \\
\hline & & & Nitrides & ; \\
\hline UN & $\begin{array}{l}\text { Gray metallic } \\
\text { crystals }\end{array}$ & & & $\begin{array}{l}U+N_{2}(<1000 \mathrm{C}) \rightarrow U_{x}(x>1) ; U N_{x} \rightarrow U N(1300-1600 \mathrm{C})^{(4)} \\
U C_{4}+\mathrm{NH}_{3}(\text { red heat }) \rightarrow U N_{x}(x>1) ; U N_{x} \rightarrow U N(1300-1600 \mathrm{C})^{(11)} \\
U+\mathrm{NH}_{3}(<1000 \mathrm{C}) \rightarrow \mathrm{UN}_{\mathrm{x}}(\mathrm{x}>1) ; \mathrm{UN}_{\mathrm{x}} \rightarrow \mathrm{UN}(1300-1600 \mathrm{C})^{(4)}\end{array}$ \\
\hline & & & Sulfides & \\
\hline US & $\begin{array}{l}\text { Gray metallic } \\
\text { crystals }\end{array}$ & & $\mathrm{UOS}+\mathrm{C} \rightarrow \mathrm{US}+\mathrm{CO}(1900 \mathrm{C})^{(3)}$ & $\begin{array}{l}\mathrm{UO}_{2}+\mathrm{H}_{2} \mathrm{~S} \rightarrow \mathrm{UOS}+\mathrm{H}_{2} \mathrm{O}(<1200 \mathrm{C} \text { in graphite crucible); } \\
\mathrm{UOS}+\mathrm{CS} \rightarrow \mathrm{US}_{2}+\mathrm{CO}(>1200 \mathrm{C}) \\
\left.\mathrm{US}_{2} \rightarrow \mathrm{US}+\mathrm{S} \text { (每 vacuo at } 1600 \mathrm{C}\right)^{(1)} \\
2 \mathrm{UH}_{3}+2 \mathrm{H}_{2} \mathrm{~S} \rightarrow 2 \mathrm{US}+5 \mathrm{H}_{2}(500-600 \mathrm{C})^{(12)}\end{array}$ \\
\hline$U_{2} S_{3}$ & $\begin{array}{l}\text { Gray metallic } \\
\text { crystals }\end{array}$ & $U+3 U S_{2} \rightarrow 2 U_{2} S_{3}(1800 \mathrm{C})^{(12)}$ & & $2 \mathrm{UH}_{3}+3 \mathrm{H}_{2} \mathrm{~S} \rightarrow \mathrm{U}_{2} \mathrm{~S}_{3}+6 \mathrm{H}_{2}(500-600 \mathrm{C})^{(10)}$ \\
\hline
\end{tabular}

(a) Superscript numbers are references at the end of the report. 


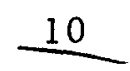

Uranium sesquicarbide $\left(\mathrm{U}_{2} \mathrm{C}_{3}\right)$ can be formed by heating a stoichiometric mixture ( $7.03 \mathrm{w} / \mathrm{o}$ carbon) at $2000 \mathrm{C}$ in vacuo and then reheating at $1600 \mathrm{C}$ while shaking the material about in the crucible. Samples containing up to $90 \mathrm{w} / \circ \mathrm{U}_{2} \mathrm{C}_{3}$ phase have been obtained in this manner. (9)

$\mathrm{UN}$ is prepared by reducing higher nitrides in vacuo at 1300-1650 C. The higher nitrides can be prepared by several methods, as shown in Table 3. Chiotti $(4)$ reported sintering UN crucibles at temperatures between 2000 and $2100 \mathrm{C}$ to approximately 85 per cent of theoretical density. These crucibles contained about $0.43 \mathrm{w} / \mathrm{o}$ carbon.

Brewer ${ }^{(12)}$ reported that US can be prepared by reacting $\mathrm{UH}_{3}$ with $\mathrm{H}_{2} \mathrm{~S}$ in a vacuum tube at 400-550 C. Hydrogen evolved from the reaction is removed by evacuation through a liquid-air cold trap. The reaction product is crushed and heated at 500-600 $\mathrm{C}$ to decompose any remaining hydride, then reheated at $1800-1900 \mathrm{C}$ in a molybdenum crucible to obtain a uniform product.

Another method of making US is to form US 2 by one of the methods described by Brewer (12) and to react the $\mathrm{US}_{2}$ stoichiometrically with $\mathrm{UH}_{3}$. The mixture of $\mathrm{US}_{2}$ and $\mathrm{UH}_{3}$ is heated to $400-600 \mathrm{C}$ to decompose the hydride and then to 2000-2200 $\mathrm{C}$ to homogenize the product.

US also can be formed by reacting $\mathrm{UO}_{2}$ and $\mathrm{H}_{2} \mathrm{~S}$ in the presence of carbon to form US 2 and subsequent reduction of $\mathrm{US}_{2}$ to US in vacuo at $1600 \mathrm{C}$. (1) $\mathrm{UO}_{2}$ was heated in $\mathrm{H}_{2} \mathrm{~S}$ in a graphite crucible below $1200 \mathrm{C}$ and UOS was formed; the temperature was then raised above $1200 \mathrm{C}$ and $\mathrm{CS}$ was formed by the reaction of $\mathrm{H}_{2} \mathrm{~S}$ and the graphite crucible. CS reacted with UOS to form US 2 .

\section{Crystallography}

Crystallographic data for the carbides, nitrides, and sulfides are given in Table 4.

Thermochemical Aspects

The standard free energy of formation of $\mathrm{UC}_{2}$ at $298 \mathrm{~K}$ was calculated to be $-42,000$ calories, based on Rossini's (13) values for $\Delta H$ and $\triangle S$ at $298 \mathrm{~K}$. $\triangle \mathrm{F}_{\mathrm{T}}$ up to $1500 \mathrm{~K}$ was computed from Kubaschewski's rule(14) by assuming $\Delta \mathrm{C}_{\mathrm{p}}=0$. 
TABLE 4. CRYSTALLOGRAPHY OF URANIUM CARBIDES, NITRIDES, AND SULFIDES

\begin{tabular}{|c|c|c|c|c|c|c|c|}
\hline \multirow[b]{2}{*}{ Compound } & \multicolumn{2}{|c|}{ Unit Cell } & \multirow[b]{2}{*}{$\begin{array}{l}\text { Molecules } \\
\text { per Unit Cell }\end{array}$} & \multirow{2}{*}{$\begin{array}{c}\text { X-Ray } \\
\text { Density, } \\
\text { geer } \mathrm{cm}^{3}\end{array}$} & \multirow[b]{2}{*}{$\begin{array}{l}\text { Space } \\
\text { Group }\end{array}$} & \multirow[b]{2}{*}{ Remarks } & \multirow[b]{2}{*}{ Reference } \\
\hline & Type & $\begin{array}{c}\text { Dimensions, } \\
\mathrm{A}\end{array}$ & & & & & \\
\hline $\mathrm{U}_{2} \mathrm{C}_{3}$ & Bcc & $a=8.088 \pm 0.001$ & 8 & 12.88 & $143 d$ & $\begin{array}{l}\text { Isostructural with } \\
\mathrm{P}_{2} \mathrm{C}_{3}\end{array}$ & (9) \\
\hline UN & $\mathrm{Fcc}$ & $a=4.880 \pm 0.001$ & 4 & 14.32 & -- & $\begin{array}{l}\mathrm{NaCl} \text {-type structure, com- } \\
\text { pletely soluble with UC }\end{array}$ & $-(2)$ \\
\hline US & $\mathrm{Bcc}$ & $\mathrm{a}=5.484 \pm 0.002$ & 4 & 10.87 & -- & $\begin{array}{l}\mathrm{NaCl} \text {-type structure, } \\
\text { soluble with ThS } \\
\text { and } \mathrm{CeS}\end{array}$ & (1) \\
\hline
\end{tabular}




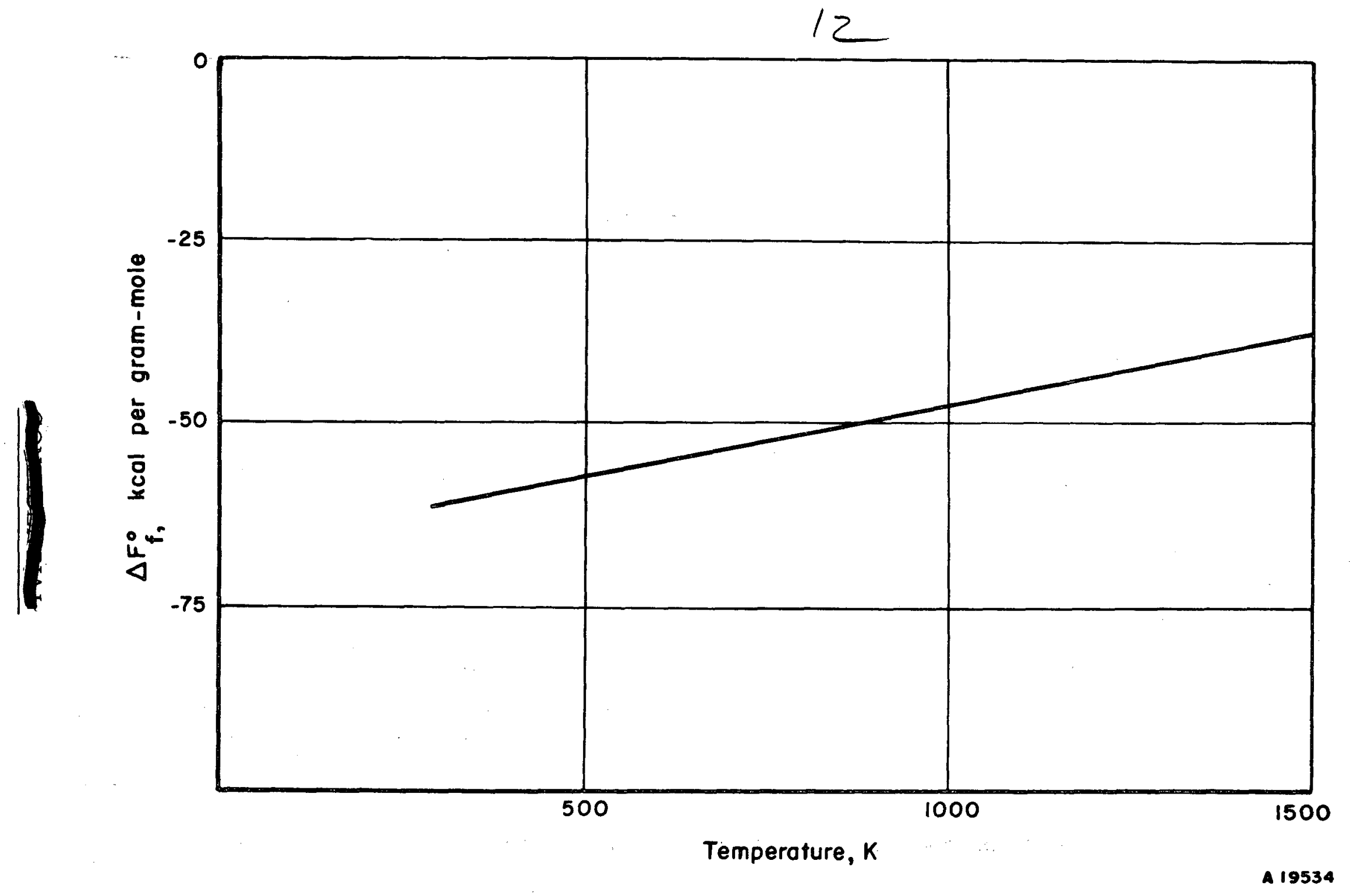

FIGURE 1. FREE ENERGY OF FORMATION OF UN 


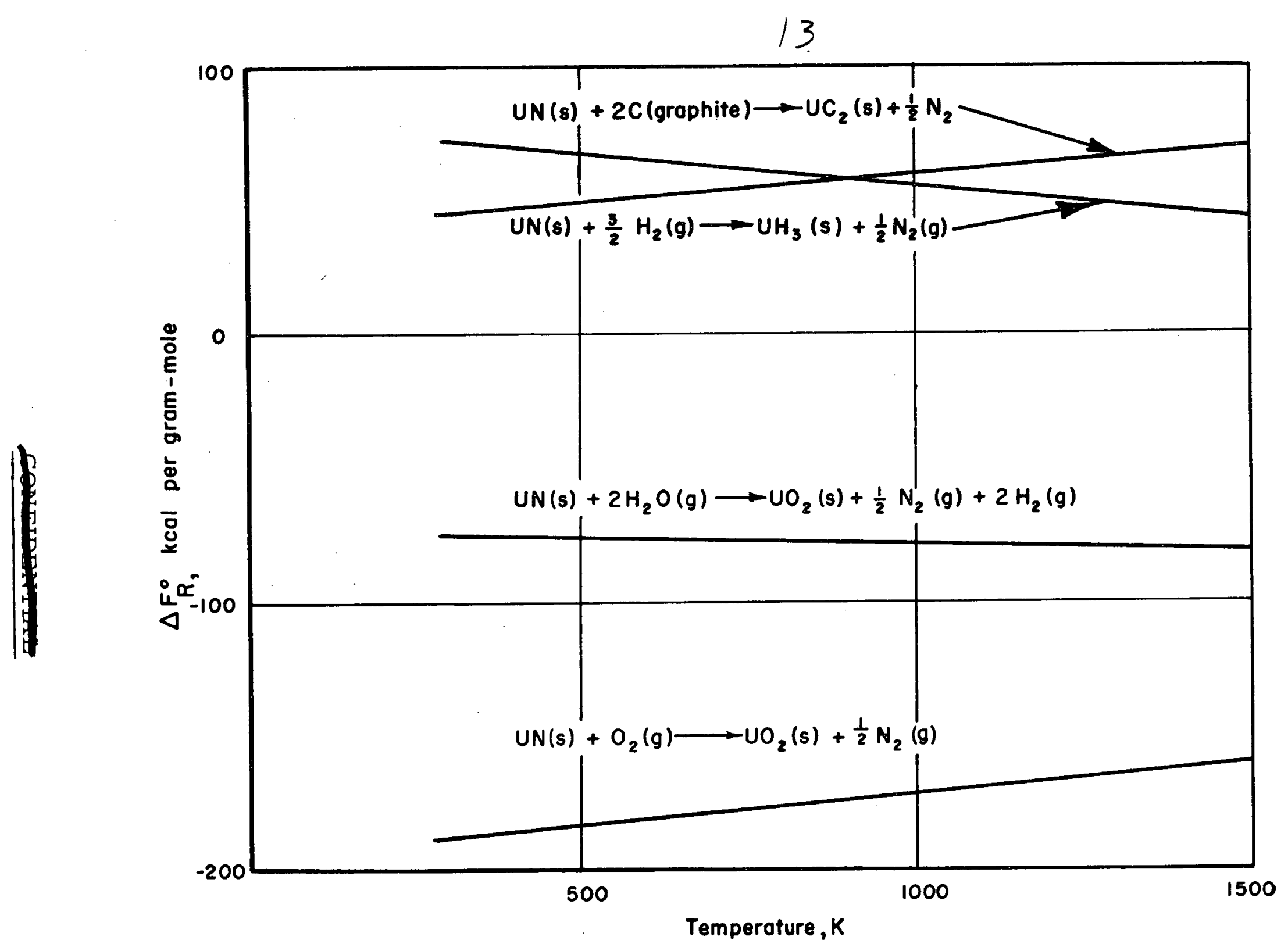

FIGURE 2. STANDARD FREE ENERGIES FOR REACTIONS OF UN WITH COMMON REAGENTS 


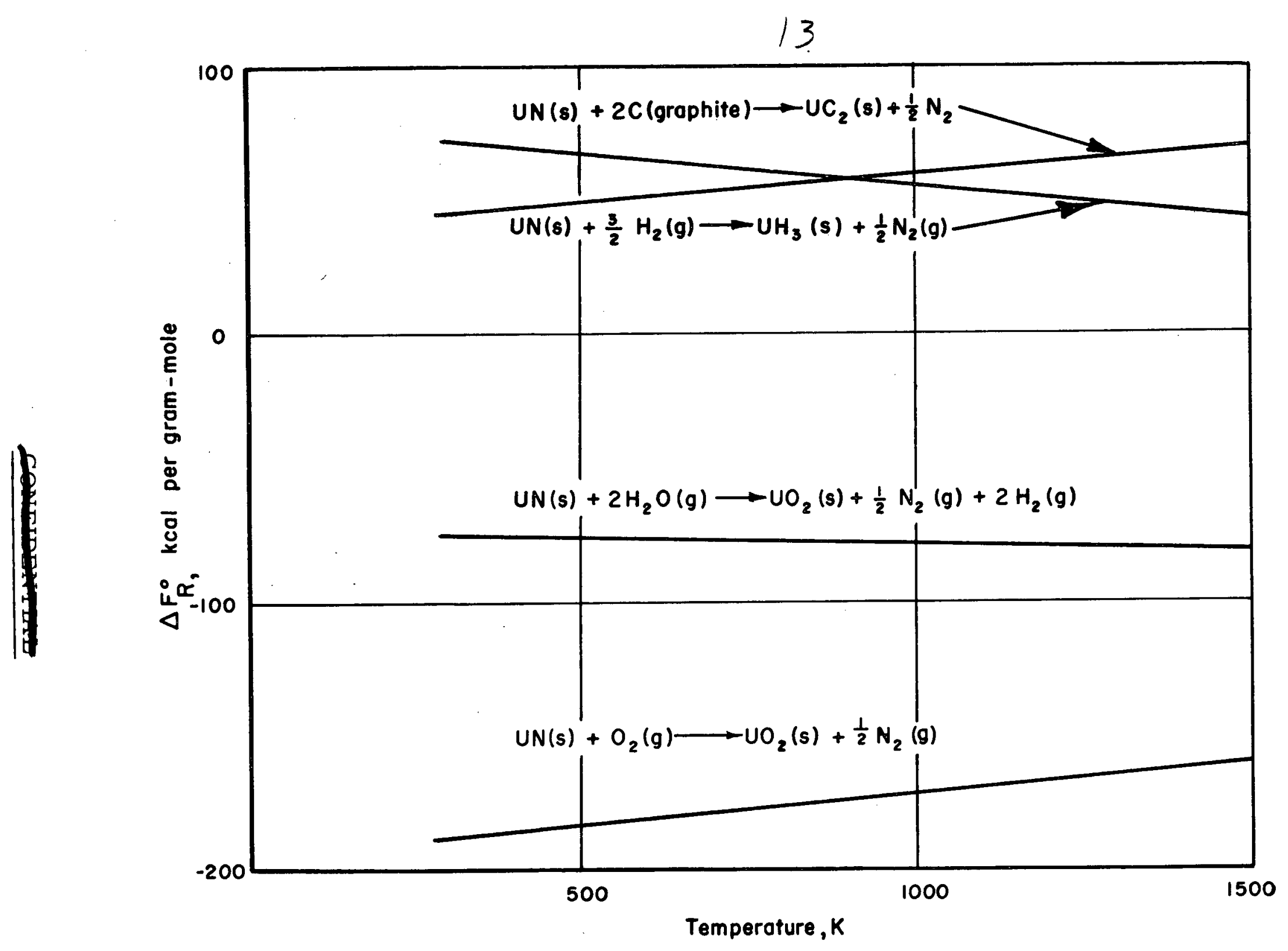

FIGURE 2. STANDARD FREE ENERGIES FOR REACTIONS OF UN WITH COMMON REAGENTS 


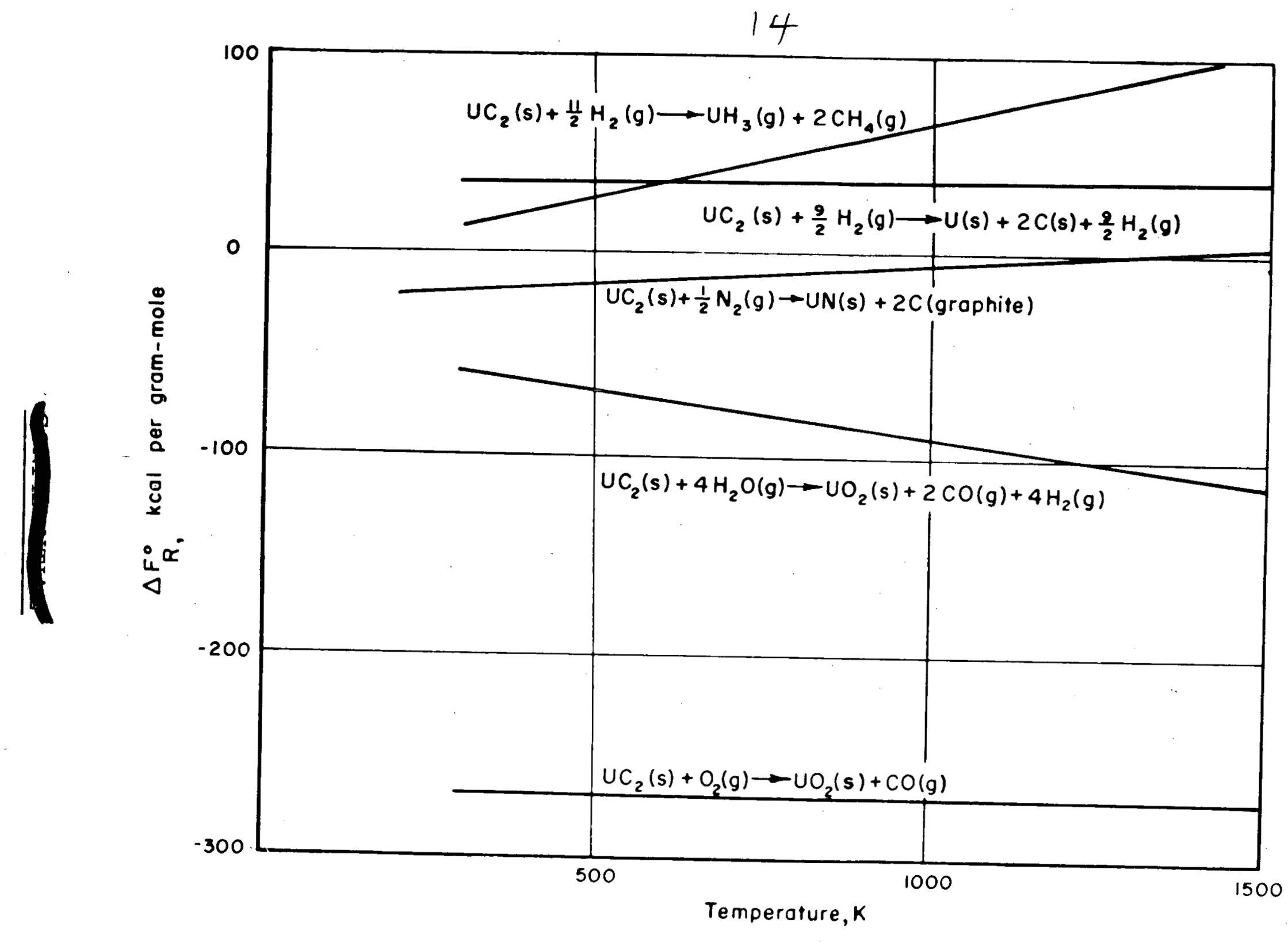

FIGURE 3. STANDARD FREE ENERGIES FOR REACTIONS OF UC 2

419536 WITH COMMON GASES 
Standard free energy of formation values for UN were calculated up to $1500 \mathrm{~K}$ and are presented in Figure 1. These calculations were based on experimental data of Kubaschewski and Evans(14).

Standard free-energy changes of several reactions of UN and of $\mathrm{UC}_{2}$ with some common gases and with carbon are presented in Figures 2 and 3.

The large negative values of standard free-energy change indicate that $\mathrm{UN}$ and $\mathrm{UC}_{2}$ should react readily with oxygen, water, or steam. They are shown to be thermodynamically unreactive with hydrogen.

Standard free-energy changes for the reaction of US with oxygen, based on an estimated value for the heat of formation of US, are shown in Figure 4 . Because of the large negative values for the calculated $\triangle F_{R}^{0}$, it is highly improbable that the estimated heat of formation is sufficiently in error that the actual $\triangle F_{\mathrm{R}}^{0}$ would be positive. Thus, it is fairly certain that, thermodynamically, US will have poor resistance to oxidation. A similar calculation showed that US is not thermodynamically resistant to steam.

\section{Chemical Properties and Corrosion Data}

Reactions of $\mathrm{UC}_{2}$ with some common elements or compounds are given in Table 5 .

$\mathrm{UC}_{2}$ reacts with water at $82 \mathrm{C}$ to give hydrogen, $\mathrm{CH}_{4}$, paraffins, and traces of $\mathrm{C}_{2} \mathrm{H}_{2}, \mathrm{CO}$, and $\mathrm{CO}_{2} \cdot(15)$ At $248 \mathrm{C}$, approximately 96 per cent of the gaseous reaction product is hydrogen.

Moissan (16) reported $\mathrm{UC}_{2}$ to be decomposed by dilute $\mathrm{HCl}, \mathrm{HNO}_{3}$, and $\mathrm{H}_{2} \mathrm{SO}_{4}$, giving yellow uranyl salt solutions. Concentrated acids, except $\mathrm{HNO}_{3}$, react only slowly with $\mathrm{UC}_{2}$ at room temperature but very rigorously when heated. Daane (17) reported a slow reaction with $\mathrm{H}_{3} \mathrm{PO}_{4}$ at room temperature and a vigorous reaction when heated.

$\mathrm{UC}_{2}$ was reported by Rideal $(18)$ to be readily decomposed by alkalis.

UC decomposes in water at $83 \mathrm{C}$ with the evolution of a gaseous mixture composed of approximately 78 per cent $\mathrm{CH}_{4}$ and 12 per cent hydrogen. As the temperature is increased, the ratio of hydrogen increases until at $400 \mathrm{C}$ the mixture contains 99.2. per cent hydrogen. (15)

US has been found to be stable in boiling water if it is well sintered. (1) 
17<smiles>C1=CC=CC=1</smiles> 
TABLE 5. CHEMICAL REACTIVITY OF UC 2

\begin{tabular}{|c|c|c|c|c|}
\hline Reactant & $\begin{array}{c}\text { Reaction Temperature, } \\
\mathrm{C}\end{array}$ & Products of Reaction & Remarks & Reference \\
\hline $\mathrm{O}_{2}$ & 370 & $\mathrm{U}_{3} \mathrm{O}_{8}$ and $\mathrm{CO}_{2}$ & -- & (16) \\
\hline $\mathrm{O}_{2}$ & $400-500$ & -- & Oxidized completely within $4 \mathrm{hr}$ in an a ir stream & $(22)$ \\
\hline $\mathrm{N}_{2}$ & 1100 & -- & -- & (16) \\
\hline $\mathrm{N}_{2}$ & 1180 & Uranium nitride & After $12 \mathrm{hr}$ all carbide is converted to nitride & (23) \\
\hline $\mathrm{Cl}_{2}$ & 350 & Volatile chloride & -- & (16) \\
\hline $\mathrm{Cl}_{2}$ & 600 & $\mathrm{UCl}_{4}$ & -- & $(24)$ \\
\hline $\mathrm{F}_{2}$ & 30 & No reaction & -- & (16) \\
\hline $\mathrm{F}_{2}$ & Slightly a bove 30 & Explosive reaction & -- & (16) \\
\hline $\mathrm{Br}_{2}$ & 390 & -- & Carbide ignites in bromine vapor & (16) \\
\hline $\mathrm{Br}_{2}$ & $800-900$ & $\mathrm{UBr}_{4}$ & -- & $(25,26)$ \\
\hline $\mathrm{I}_{2}$ & 500 & $\mathrm{UI}_{4}$ & -- & $(27)$ \\
\hline $\mathrm{NH}_{3}$ & Red heat & -- & Partial decomposition of $\mathrm{UC}_{2}$ & (16) \\
\hline $\mathrm{H}_{2} \mathrm{~S}$ & 600 & A sulfide & $U C_{2}$ ignited in hydrogen sulfide & (16) \\
\hline$s$ & -- & $\begin{array}{l}\text { Uranium sulfide and } \\
\text { carbon disulfide }\end{array}$ & - & (16) \\
\hline $\mathrm{HCl}$ & 600. & A uranium chloride & -- & (16) \\
\hline $\mathrm{H}_{2} \mathrm{O}$ & -- & Hydrocarbons & $\begin{array}{l}\text { Decomposes slowly at room temperature, } \\
\text { decomposes rapidly when heated }\end{array}$ & (16) \\
\hline
\end{tabular}




\section{Physical Properties}

The boiling point of $\mathrm{UC}_{2}$ was estimated by Mott(19) to be $4370 \mathrm{C}$ under $760 \mathrm{~mm}$ of mercury.

Two values for the thermal conductivity of UChave been reported: $0.078(20)$ and $0.082^{(21)} \mathrm{cal} /(\mathrm{sec})\left(\mathrm{cm}^{2}\right)(\mathrm{C} / \mathrm{cm})$. The former value is for a temperature of $44 \mathrm{C}$ while the temperature of the latter measurement was not specified.

The average coefficient of thermal expansion of $\mathrm{UC}_{2}$ for the temperature range $20-235 \mathrm{C}$ was reported to be $12.5 \times 10^{-6}$ per deg C. (28)

\section{URANIUM SILICIDES AND BORIDES}

\section{$\underline{\text { Preparation }}$}

Uranium silicides (U3Si, U3Si2, USi, alpha USi2, beta USi2, and USi3) were prepared as part of the present research by heating stoichiometric mixtures of the elements in an electric arc furnace. Fabrication of shapes from the arc melts was accomplished by ceramic techniques.

Some of the as-cast uranium-silicon compounds crystallized as multiphase materials and had to be annealed to remove extraneous phases. This generally was done by extended heating of the ingot in an inert atmosphere near the melting or decomposition temperature. Annealing also was affected during sintering processes.

$\mathrm{U}_{3} \mathrm{Si}$ is more ductile than the other uranium silicides. It has been coextruded with other metals at 750-800 C. (29)

Brewer $(6)$ and Zalkin $(30)$ prepared gray metallic crystals of $\mathrm{UB}_{2}$ and UB4 by heating stoichiometric mixtures of uranium and boron powde $r$ in an inert atmosphere in molybdenum crucibles at $1500 \mathrm{C}$ for about $1 \mathrm{hr}$.

\section{Crystallography}

Crystallographic data on the uranium silicides and borides are listed in Table 6. 
TABLE 6. CRYSTALLOGRAPHY OF URANIUM SILICIDES AND URANIUM BORIDES

\begin{tabular}{|c|c|c|c|c|c|c|c|}
\hline \multirow[b]{2}{*}{ Compound. } & \multicolumn{2}{|c|}{ Unit Cell } & & \multirow[b]{2}{*}{ Remarks } & \multirow[b]{2}{*}{ Reference } \\
\hline & Type & $\begin{array}{c}\text { Dimensions, } \\
\mathrm{A} \\
\end{array}$ & $\begin{array}{c}\text { Molecules } \\
\text { per Unit Cell } \\
\end{array}$ & $\begin{array}{l}\text { Density, } \\
\text { g per } \mathrm{cm}^{3} \\
\end{array}$ & $\begin{array}{l}\text { Space } \\
\text { Group }\end{array}$ & & \\
\hline $\mathrm{U}_{3} \mathrm{Si}$ & $\begin{array}{l}\text { Bc te tragonal } \\
\text {.. }\end{array}$ & $\begin{array}{l}a=6.029 \pm 0.002 \\
c=8.697 \pm 0.003\end{array}$ & 4 & 15.58 & $14 \mathrm{mcm}$ & - & $\begin{array}{l}(31) \\
(32)\end{array}$ \\
\hline $\mathrm{U}_{3} \mathrm{Si}_{2}$ & Tetragonal & $\begin{array}{l}a=7.3298 \pm 0.0004 \\
c=3.9003 \pm 0.0005\end{array}$ & 2 & 12.20 & $\mathrm{P}_{4} / \mathrm{mbm}$ & -- & (33) \\
\hline USi & Orthorhombic & $\begin{array}{l}a=5.66 \pm 0.01 \\
b=7.66 \pm 0.01\end{array}$ & 4 & 10.40 & Pbnm & Isomorphous with $\mathrm{FeB}$ & $(31,32)$ \\
\hline Alpha USi 2 & Bc tetragonal & $\begin{array}{l}a=3.98 \pm 0.03 \\
c=13.74 \pm 0.08\end{array}$ & 4 & 8.98 & $14 /$ amd & $\begin{array}{l}\text { Isomorphous with } \mathrm{Th} \mathrm{Si}_{2} \text {, } \\
\text { PuSi }_{2}, \mathrm{CeSi} i_{2} \text {, and } \mathrm{NpSi}_{2}\end{array}$ & $(31,32)$ \\
\hline Beta $\mathrm{USi}_{2}$ & Hexagonal & $\begin{array}{l}a=3.86 \pm 0.01 \\
c=4.07 \pm 0.01\end{array}$ & 1 & 9.25 & $\mathrm{C} 6 / \mathrm{mmm}$ & $\begin{array}{l}\text { Isomorphous with } \mathrm{AlB}_{2} \\
\text { and } \mathrm{TiB}_{2}\end{array}$ & (33) \\
\hline $\mathrm{USi}_{2}$ & Cubic & $a=4.035$ & $\cdots$ & 7.80 & -- & $\cdots$ & (34) \\
\hline $\mathrm{USi}_{3}$ & Cubic & $a=4.03$ & 1 & 8.15 & $\mathrm{Pm} 3 \mathrm{~m}$ & $\begin{array}{l}\text { L12-type } \mathrm{AuCu}_{3} \text { ordered } \\
\text { structure }\end{array}$ & $(31.32)$ \\
\hline $\mathrm{UB}_{2}$ & Hexagonal & $\begin{array}{l}a=3,12 \\
c=3.96\end{array}$ & 1 & 12.82 & - & $\begin{array}{l}\text { May be isomorphous with } \\
\mathrm{AlB}_{2}\end{array}$ & (29) \\
\hline $\mathrm{UB}_{4}$ & Tetragonal & $\begin{array}{l}a=7.075 \pm 0.004 \\
c=3.979 \pm 0.002\end{array}$ & 4 & 9.38 & $\mathrm{P}_{4} / \mathrm{mbm}$ & $\begin{array}{l}\text { Isomorphous with } \mathrm{ThB}_{4} \\
\text { and } \mathrm{CeB}_{4}\end{array}$ & $(30)$ \\
\hline
\end{tabular}


The constitutional diagram of the uranium-silicon system, as determined by Kaufmann $(31,32)$ indicates the existence of the intermediate phases, $\mathrm{U}_{3} \mathrm{Si}, \mathrm{U}_{5} \mathrm{Si}_{3}, \mathrm{USi}, \mathrm{U}_{2} \mathrm{Si}_{3}, \mathrm{USi}_{2}$, and USi3. However, there is some doubt whether this diagram is accurate in the region 5 to $30 \mathrm{w} / 0$ silicon. In later work, Zachariasen (33) rejected the formulas $\mathrm{U}_{5} \mathrm{Si}_{3}$ and $\mathrm{U}_{2} \mathrm{Si}_{3}$. His interpretation of the $\mathrm{X}$-ray diffraction data was that $\mathrm{U}_{5} \mathrm{Si}_{3}$ should be replaced by $\mathrm{U}_{3} \mathrm{Si}_{2}$, and that the phase identified by Kaufmann as $\mathrm{U}_{2} \mathrm{Si}_{3}$ is an allotrope of USi2 with a hexagonal structure. Zachariasen called this compound beta $\mathrm{USi}_{2}$. It is not quite clear whether Zachariasen's samples were of the same composition as those of Kaufmann as no chemical analyses were given.

Brauer and Haig $(34)$ identified a cubic phase with the USi2 composition. Their samples were prepared in a molten aluminum bath and analyzed $19 \mathrm{w} / 0$ silicon and $80.7 \mathrm{w} / \mathrm{o}$ uranium.

\section{Thermochemical Aspects}

No experimental thermochemical data were found on the uranium silicides or borides. Estimates of the standard free energies of reaction of $\mathrm{USi}_{2}$ and $\mathrm{UB}_{2}$ with oxygen and water are shown in Figure 5. The predictions are based on Battelle estimates of heats of formation. The large negative values of the standard free-energy changes indicate that neither $\mathrm{USi}_{2}$ nor $\mathrm{UB}_{2}$ is thermodynamically resistant to oxidation. As USi2 probably is the most stable of the uranium silicides, none of the other silicides would be expected to have thermodynamic resistance to oxygen.

The silicides and borides appear to be the rmodynamically resistant to hydrogen but not to water vapor, on the basis of Battelle estimates.

\section{Chemical Properties and Corrosion Data}

Data obtained at Battelle on the chemical stability of $\mathrm{U}_{3} \mathrm{Si}$ and alpha $\mathrm{USi}_{2}$ in acidic and basic solutions and in hydrogen gas are shown in Table 7. The results of corrosion tests in water of $\mathrm{U}_{3} \mathrm{Si}$ and alpha USi2 are given in Table 8 .

$\mathrm{U}_{3} \mathrm{Si}$ is reported to resist oxidation in air at 100 and $200 \mathrm{C}$, but not at $300 \mathrm{C}$. (35) It corrodes only slightly faster in steam at $125 \mathrm{psi}$ than in boiling water. (35) The surface was roughened and a slight weight gain was observed after $5 \mathrm{hr}$ in a lead-bismuth eutectic mixture at $425 \mathrm{C}$. (35)

Measurements made at Battelle on air oxidation of uranium silicides at $400 \mathrm{C}$ are given in Table 9. In general, oxidation resistance in air 


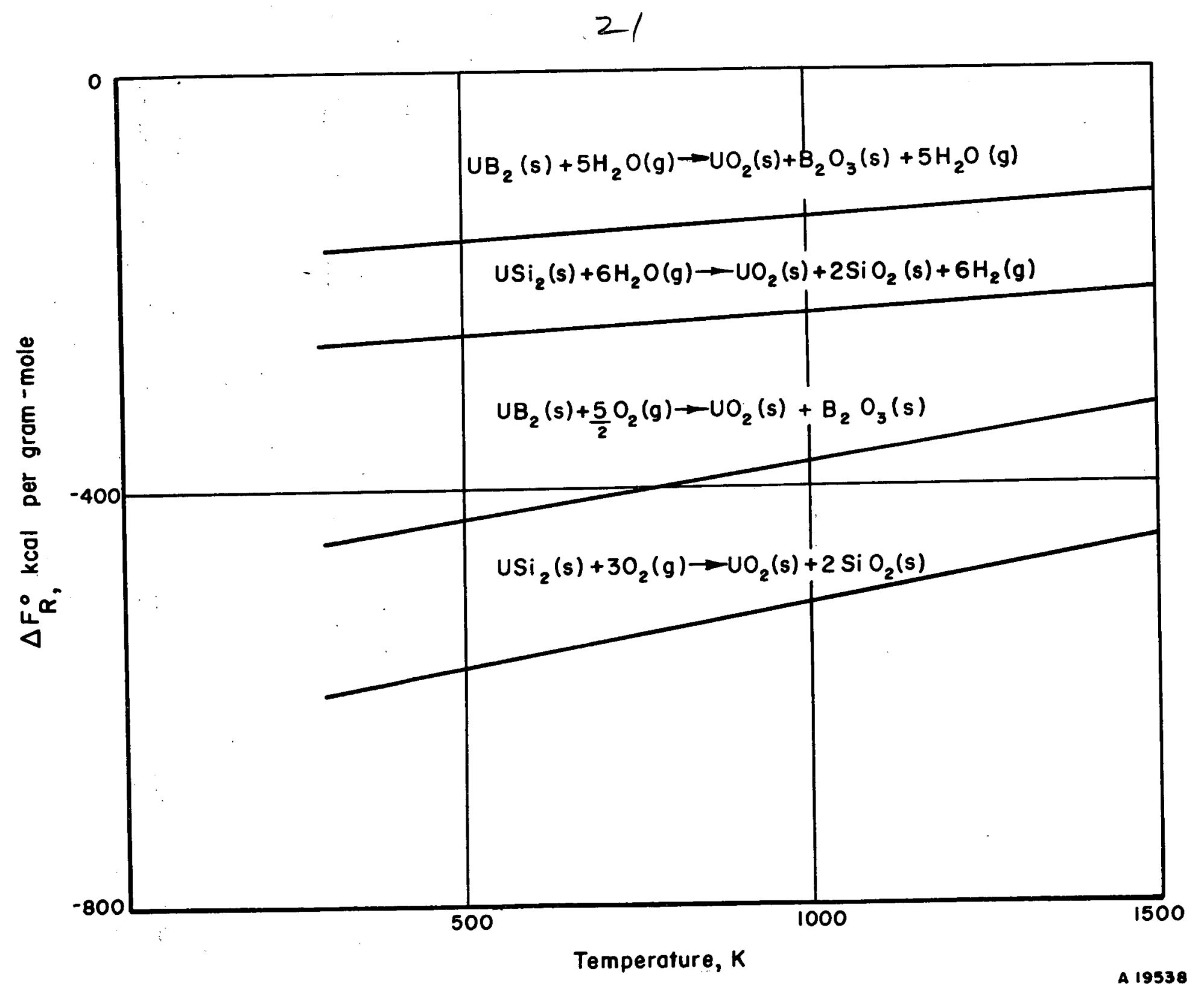

FIGURE 5. STANDARD FREE ENERGIES FOR REACTIONS OF USi ${ }_{2}$ AND UB $_{2}$ WITH $\mathrm{H}_{2} \mathrm{O}$ AND $\mathrm{O}_{2}$ 
TABLE 7. CHEMICAL STABILITY OF $\mathrm{U}_{3}$ Si AND ALPHA USi ${ }_{2}^{(a)}$

\begin{tabular}{|c|c|c|c|c|c|}
\hline \multirow[b]{2}{*}{ Compound } & \multicolumn{3}{|c|}{$\begin{array}{c}\text { Stability in Indicated } \\
\text { Concentrated Acid }\end{array}$} & \multirow{2}{*}{$\begin{array}{l}\text { Stability in } \\
1 \mathrm{~N} \mathrm{NaOH}\end{array}$} & \multirow{2}{*}{$\begin{array}{l}\text { Weight Change A fter } \\
\text { 1-Hr Exposure in } 500 \mathrm{C} \\
\text { Hydrogen, per cent }\end{array}$} \\
\hline & $\mathrm{HCl}$ & $\mathrm{HNO}_{3}$ & $\mathrm{H}_{2} \mathrm{SO}_{4}$ & & \\
\hline $\mathrm{U}_{3} \mathrm{Si}^{(\mathrm{b})}$ & Reacted & Reacted & Reacted & No reaction & +0.62 \\
\hline Alpha USi ${ }^{(b)}$ & Reacted & Reacted & Reacted & No reaction & +0.60 \\
\hline Alpha USi ${ }_{2}{ }^{(c)}$ & Reacted & Reacted & Slow reaction & No reaction & +0.08 \\
\hline
\end{tabular}
(a) Data obtained at Battelle.
(b) Arc melt.
(c) Compact sintered at $1400 \mathrm{C}$ in argon.

TABLE 8. CORROSION RESISTANCE OF U 3 Si AND ALPHA USi 2 IN WATER

\begin{tabular}{|c|c|c|}
\hline Compound & $\begin{array}{c}\text { Weight Loss After } 1 \mathrm{Hr} \text { in } \\
\text { Boiling Water, } \\
\text { per cent }\end{array}$ & $\begin{array}{c}\text { Weight Change in } \\
650 \mathrm{~F} \mathrm{Water,} \\
\mathrm{mg} /\left(\mathrm{cm}^{2}\right)(\mathrm{hr})\end{array}$ \\
\hline $\mathrm{U}_{3} \mathrm{Si}^{(\mathrm{a})}$ & 0.00 & -1.00 \\
\hline $\mathrm{U}_{3} \mathrm{Si}^{(\mathrm{b})}$ & -- & -1.00 \\
\hline $\mathrm{USi}_{2}(\mathrm{c})$ & 0.00 & -2.00 \\
\hline
\end{tabular}

(a) Data obtained at Battelle on epsilonized arc melt.

(b) Data obtained by WAPD(29) on extruded bar.

(c) Data obtained at Battelle on compact sintered at $1400 \mathrm{C}$ in argon. 
TABLE 9. OXIDA TION IN AIR OF URANIUM SILICIDES

\begin{tabular}{|c|c|c|}
\hline Compound & $\begin{array}{c}\text { Silicon Content, } \\
\text { w/o }\end{array}$ & $\begin{array}{c}\text { Weight Gain in } 7-1 / 2 \mathrm{Hr} \\
\text { at } 400 \mathrm{C} \text {, per cent }\end{array}$ \\
\hline $\mathrm{U}_{3} \mathrm{Si}$ & 3.8 & 19.6 (disintegrated) \\
\hline $\mathrm{U}_{3} \mathrm{Si}_{2}$ & 7.25 & $\begin{array}{l}18.5 \text { (disintegrated } \\
1.4 \text { (a) }\end{array}$ \\
\hline USi & 10.5 & 16.5 (disintegrated) \\
\hline Alpha USi 2 & 19.0 & $\begin{array}{l}0.19^{(b)} \\
0.14^{(a)}\end{array}$ \\
\hline $\mathrm{USi}_{3}$ & 26.0 & $0.07(c)$ \\
\hline
\end{tabular}

(a) Contained approximately 3 to $5 \mathrm{w} / \mathrm{o}$ iron.

(b) Contained approximately 1 w/o tungsten.

(c) Contained approximately $4 \mathrm{w} / \mathrm{o}$ tungsten.: :

Note: Data obtained at Battelle. Specimens weighed approximately $2.5 \mathrm{~g}$, and were $1 / 2$ in. in diameter by $1 / 4$ in. long. 
increased with increasing silicon content, although the results on USi 2 and $\mathrm{USi}_{3}$ may have been influenced by impurities. The presence of 3 to $5 \mathrm{w} / \mathrm{o}$ iron in $\mathrm{U}_{3} \mathrm{Si}_{2}$ greatly improved its oxidation resistance.

\section{Physical Properties}

The thermal conductivity of $\mathrm{U}_{3} \mathrm{Si}$ was measured by Foote ${ }^{(36)}$, with the following results:

$\begin{array}{cr}\text { Temperature, C } & \frac{\text { Thermal Cond }}{\mathrm{cal} /(\mathrm{sec})\left(\mathrm{cm}^{2}\right)} \\ 50 & 0.036 \\ 50 & 0.041\end{array}$

Coefficients of linear thermal expansion for $\mathrm{U}_{3} \mathrm{Si}, \mathrm{U}_{3} \mathrm{Si}_{2}$, and $\mathrm{USi}_{3}$ are given in Table 10 .

The data of Kaufmann ${ }^{(32)}$ on the strength of $\mathrm{U}_{3} \mathrm{Si}$ in compression and tension are given in Table 11 .

\section{COMPOUNDS WITH METALS}

\section{$\underline{\text { Preparation }}$}

Compounds of uranium with aluminum, iron, or nickel were prepared at Battelle by melting stoichiometric mixtures of the elements in an electric arc furnace. The products were brittle, and fabrication of shapes required ceramic techniques.

\section{Crystallography}

Crystallographic data for compounds of uranium with aluminum, iron, or nickel are given in Table 12 .

The compound $\mathrm{UAl}_{2}$ was tentatively identified by Gordon and Kaufmann (37) on the basis of microscopic examination of alloys and X-ray determinations of crystal structure. Because of difficulties with chemical 
TABLE 10. THERMAL EXPANSIONS OF URANIUM SILICIDES $(a)$

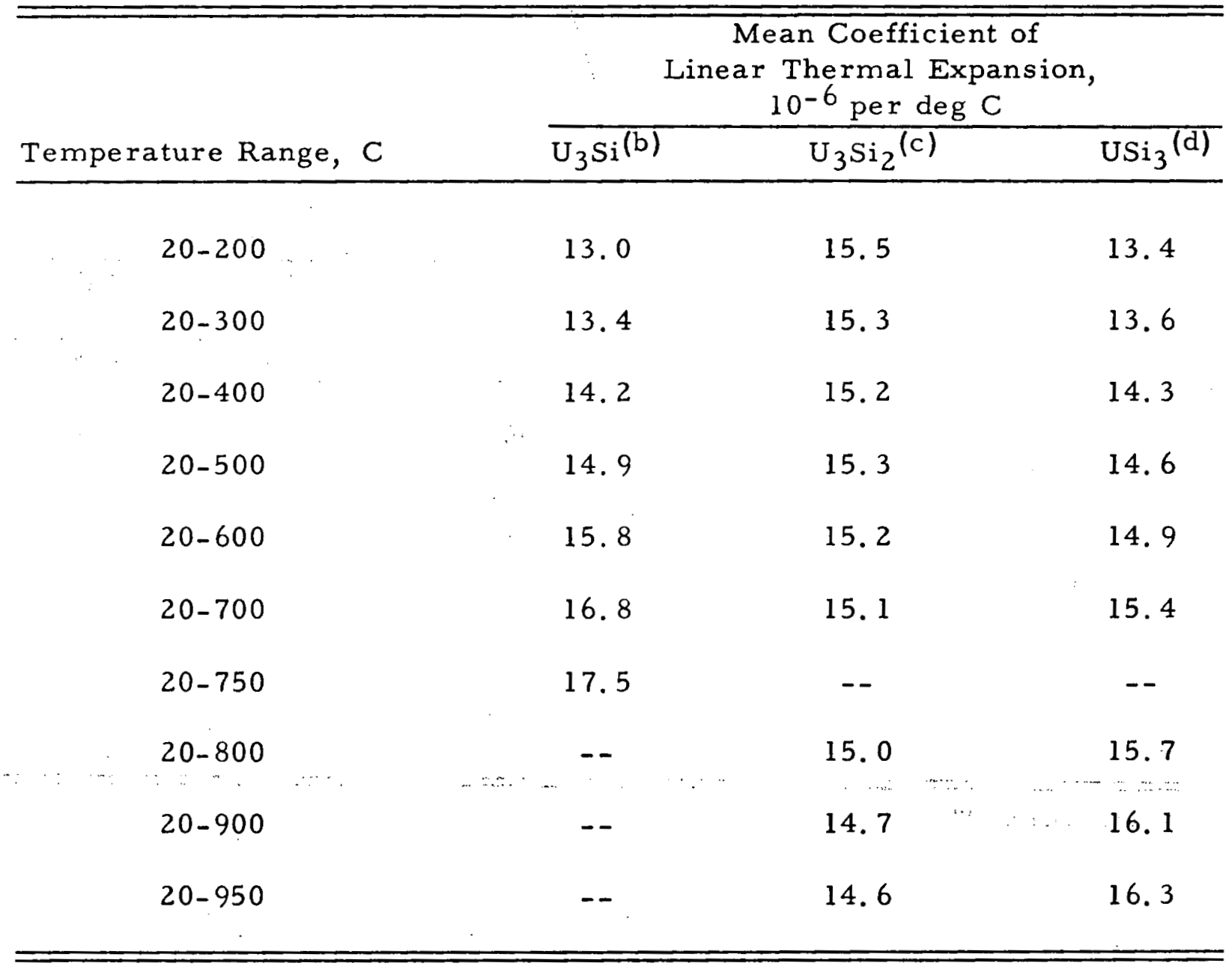

(a) Data obtained at Battelle.

(b) As-cast-ingot epsilonized at $800 \mathrm{C}$ for $168 \mathrm{hr}$.

(c) $\mathrm{U}_{3} \mathrm{Si}_{2}$ powder sintered at $1400 \mathrm{C}$ in argon for $15 \mathrm{hr}$.

(d) $\mathrm{USi}_{3}$ powder sintered at $1250 \mathrm{C}$ in argon for $15 \mathrm{hr}$. Contained approximately $4 \mathrm{w} / \mathrm{o}$ tungsten. 
TABLE 11. STRENGTH OF $\mathrm{U}_{3} \mathrm{Si}(\mathrm{a})$

\begin{tabular}{ccccc}
\hline & \multicolumn{2}{c}{$\begin{array}{c}\text { Yield Strength, } \\
\text { psi }\end{array}$} & \multicolumn{2}{c}{$\begin{array}{c}\text { Ultimate Strength, } \\
\text { psi }\end{array}$} \\
\cline { 2 - 5 } Temperature, C & Tension & Compression & Tension & Compression \\
\hline 600 & 37,000 & 115,000 & 37,000 & 280,000 \\
700 & 55,000 & & \\
750 & 18,000 & \\
850 & 10,000 & \\
\hline
\end{tabular}

(a) From Kaufmann, ${ }^{(32)}$ 


\section{7}

TABLE 12. CRYSTALLOGRAPHY OF URANIUM COMPOUNDS WITH METALS

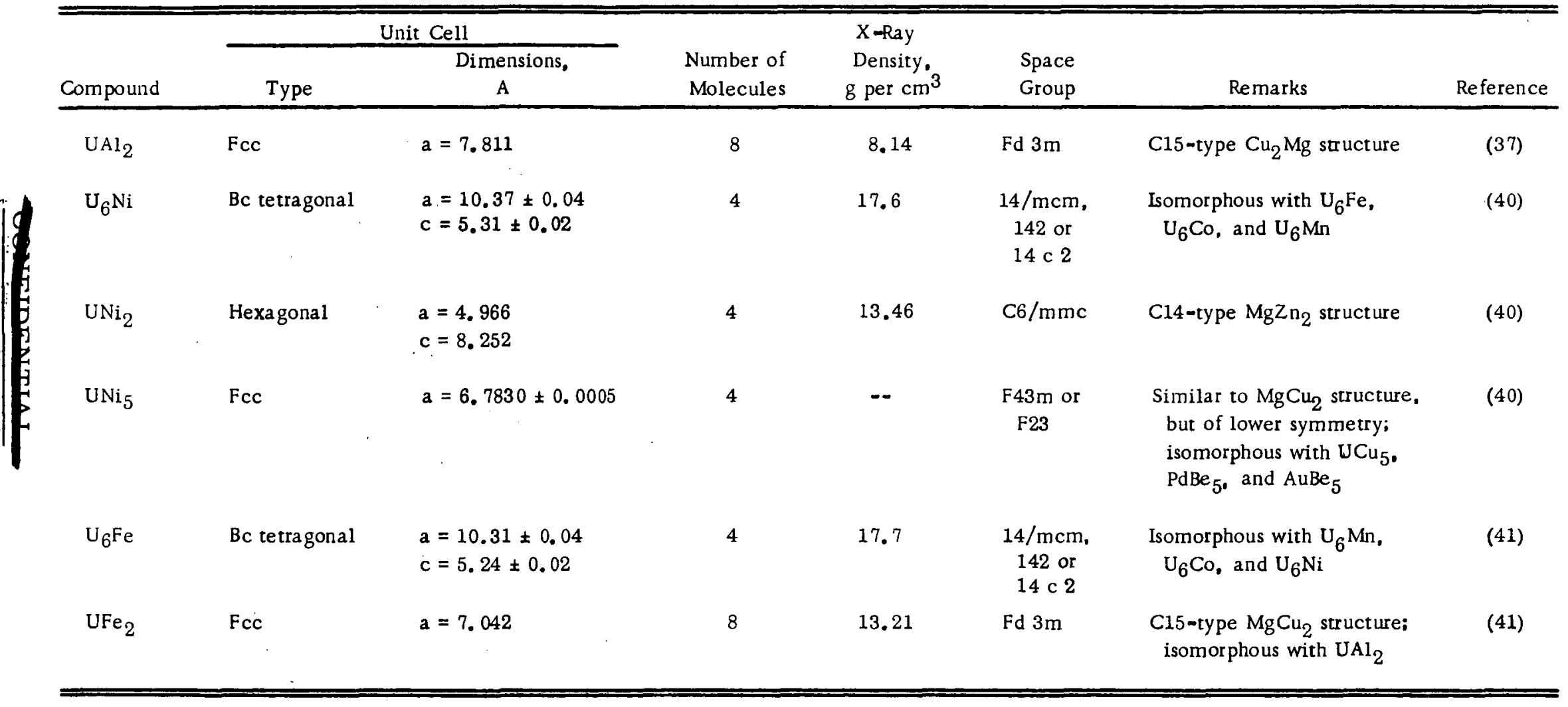


analyses and with inhomogeneity in their alloys, the composition could not be fixed to better than \pm 2 a/o. However, the measured density $18.21 \mathrm{~g}$ per $\mathrm{cm}^{3}$ ) of their sample corresponded closely with the calculated X-ray density $\left(8.38 \mathrm{~g}\right.$ per $\left.\mathrm{cm}^{3}\right)$.

The uranium-nickel system has been investigated by Grogan and Pleasance (38), Foote (39), and Baenziger(40). The data in Table 12 are from Baenziger. He also attempted to analyze the pattern of an alloy with the composition UNi but was unable to resolve its complex structure.

\section{$\underline{\text { Properties }}$}

No data on the physical or chemical properties of these compounds were found. Also, there are no reliable methods of estimating their the rmodynamic properties.

\section{REFERENCES}

Note: Reference numbers marked with an asterisk were taken from "The Chemistry of Uranium", Part I, J. J. Katz and E. Rabinowitch, National Nuclear Energy Series, VIII-5 (1951).

(1) Eastman, E. D., Brewer, L., Bromley, L. A., Gilles, P. W., and Lofgren, N. L., "Preparation and Properties of the Sulfides of Thorium and Uranium", J. Am. Chem. Soc., 72, 4019-4023 (1950).

(2) Rundle, R. E., Baenziger, N. C., Wilson, H. S., and McDonald, R. A., "The Structures of the Carbides, Nitrides, and Oxides of Uranium", J. Am. Chem. Soc。, 70, 99-105 (1948).

(3) Mallett, M. W., Gerds, A. F., and Nelson, H. R., "The Uranium Carbon System", J. Electrochem. Soc., 99, 197-204 (1952).

(4) Chiotti, P., "Experimental Refractory Bodies of High-Melting Nitrides, Carbides, and Uranium Dioxide", J. Am. Ceram. Soc., 35, $123-130$ (1952).

(5) Saller, H. A., and Rough, F. A., "Compilation of U. S. and U. K. Uranium and Thorium Constitutional Diagrams", BMI-1000 (June, 1955).

(6) Brewer, L., Sawyer, D. L., Templeton, D. H., and Dauben, C. H., "A Study of the Refractory Borides", J. Am. Ceram. Soc., 34, 173-179 (1951). 
*(25) Spedding, F. H., CC-298 (October 16, 1942).

*(26) Powe11, T., CC-1778 (August 18, 1944).

*(27) MacWood, G. E., and Altman, D., UCRL-1, RL 4.7.600 (October 24, 1944).

(28) Unpublished Battelle data (1948).

(29) Losco, E. F., and Shipiro, C. M., "Résumé of Uranium Alloy Data, IX", WAPD-PMM-262 (September 1, 1955).

(30) Zalkin, A., Templeton, D. H., "The Crystal Structures of CeB 4 , ThB 4 , and $\mathrm{UB}_{4}{ }^{\prime \prime}$, Acta Cryst., 6, 269-272 (1953).

(31) Kaufmann, A. R., and Cullity, B. D., "Alloys of Uranium and Silicon, I, The Uranium-Silicon Phase Diagram", CT-3310 (June, 1945).

(32) Kaufmann, A. R., and Bitsianes, Gust, "Alloys of Uranium and Silicon, II, The Epsilon Phase", CT-3309 (June, 1945).

(33) Zachariasen, W. H., "Crystal Chemistry Studies of the $5 f$-Series of Elements, VIII, Crystal Structure Studies of Uranium Silicides and $\mathrm{CeSi}_{2}$, NpSiz, and PuSiz", Acta Cryst., 2, 94 (1949).

(34) Brauer, V. G., and Haig, H., Z. anorg. Chem., 259 (1949).

(35) Losco, E. F., WAPD Technical Progress Report for Period January 13 to February 23, 1956", "Pressurized Water Reactor Program", WAPD-MRP-60.

(36) Foote, F., CT-2668 (January 23, 1945).

(37) Gordon, P., and Kaufmann, A. R., "Uranium-Aluminum and Uranium-Iron", J. Metals, 182 (1950).

(38) Grogan, J. D., and Pleasance, R. J., "A Survey of the UraniumNickel System", J. Inst. Metals, 82, 141-147 (1953-54).

(39) Foote, F., Clark, I. R., Cieslicki, M., Nelson, B. J., and Lane, T. R., Unpublished (1945); given in BMI-1000, see Reference (5).

(40) Baenziger, N. C., Rundle, R. E., Snow, A. I., and Wilson, A. S., "Compounds of Uranium with the Transition Metals of the First Long Period", Acta Cryst.; 3, 34-40 (1 
